\title{
Labyrinthe
}

14 | 2003

Constructions de la raison

\section{L'historien et la rationalité des acteurs}

\section{Pierre Savy}

\section{OpenEdition}

Journals

Édition électronique

URL : http://journals.openedition.org/labyrinthe/601

DOI : 10.4000/labyrinthe.601

ISSN : 1950-6031

Éditeur

Hermann

Édition imprimée

Date de publication : 1 mai 2003

Pagination : 65-71

Référence électronique

Pierre Savy, «L'historien et la rationalité des acteurs », Labyrinthe [En ligne], 14 | 2003, mis en ligne le 11 avril 2005, consulté le 08 mai 2019. URL : http://journals.openedition.org/labyrinthe/601 ; DOI : 10.4000/labyrinthe.601

Ce document a été généré automatiquement le 8 mai 2019.

Propriété intellectuelle 
L'historien et la rationalité des acteurs

Pierre Savy 